Okhrimenko Alla, Ph.D. in Economics, Associate Prof., Kyiv National University of Trade and Economics (Ukraine), Kyiv, Ukraine

ORCID: 0000-0003-0405-3081

Researcher ID: N-5566-2016

Babushko Svitlana,

Doctor of Sciences (Pedagogy), Associate Prof., National University of Ukraine on Physical Education and Sports,

ORCID: 0000-0001-8348-5936

Researcher ID: F-9475-2019

Opanasiuk Nataliia,

Ph.D. in Law, Associate Prof., National University of Ukraine on Physical Education and Sports (Ukraine), ORCID: 0000-0001-7418-8622

\title{
PUBLIC GOVERNANCE OF NATIONAL TOURISM SYSTEM
}

The article is devoted to the research of public management of the national tourism system (NTS), which is a component of the national economy. It has been found that, as a complex, multi-structural and determining entity for the national economy, NTS requires modern and balanced approaches to governance that are based on the values of civil society, democracy, partnership between the state, private and public bodies. There have been identified main areas of NTS management and proposed to consider them as a synergistic concept of effective regulatory influence on the functioning of the tourism system.

Keywords: tourism, national tourism system, public governance, regulation.

\section{Охріменко Алла, Бабуико Світлана, Опанасюк Наталія. Публічне управління національною туристичною системою.}

Стаття присвячена дослідженню публічного управління нащіональною туристичною системою (НТС), щу є складовою національної економіки. 3 'ясовано, щояк складне, поліструктурне та визначальне для національної економіки утворення - НТС потребує сучасних і збалансованих підходів до управління, які базуються на иінностях громадянського суспільства, демократії, партнерства між державою, приватними та громадськими структурами. Визначено основні сфери управління НТС та запропоновано розглядати їх як синергетичний 
концепт ефективного регламентуючого впливу на функиіонування туристичної системи.

Ключові слова: туризм, національна туристична система, управління, публічне управління, публічно-приватне партнерство, регулювання.

Relevance of research topic. Modern political, legal, socio-economic processes and global challenges lead to significant changes in society, economy and lawmaking. As a result, they actualize the problems of effective development of public governance mechanisms in all spheres of human life, including tourism. Therefore, an important scientific task is to research the effectiveness of public management of the national tourism system, as well as the implementation of modern principles of public governance in the sphere of its functioning.

Formulation of the problem. The modern realities of post-industrial digital society require a rethinking of the place and role of tourism, not only as a catalyst for positive economic change, but also as a powerful communicator of international relations, an effective means of humanitarian policy and sustainable development. In this context, it is fully justified to consider tourism as a multi-structural complex - the national tourism system (NTS), a component of the national economy as «the national tourism system reflects the complex and dynamic socio-ecological and economic nature of tourism and is a subsystem of the national economy and the global tourism system» (Mazaraki, Boiko, Bosovska, Vedmid \& Okhrimenko, 2018, p. 73). As a complex, multi-structural and determining entity for national economy, the NTS requires modern and balanced approaches to its governance. Therefore, taking into account its relevance, problematic character and to some extent innovativeness, the implementation of ideas and principles of public management in the sphere of functioning of the national tourism system is theoretically and practically significant.

Analysis of recent researches and publications. The evolution of public management was characterized by different determinants, stages, processes. The fundamental scientific basis of public administration is the concept of administrative management, which originated in the 1930s. Under the influence of humanitarian scientific trends, the theory of human resource management, the theory of organizational development, there has been formed one of the earliest areas of public management - traditional public governance.

At the present stage, public administration has not lost its relevance, but rather has become a systemic scientific concept and practical activity. In the publications of world and mostly European scholars, Klijn\&Koppenjan (2000), Hall (2011),Ostrom (2009), Koopmans, Rogge, Mettepenningen, Knickel \& Sumane (2017) there is substantiated the need to introduce new macroeconomic governance models capable of enhancing the effectiveness of state-society cooperation and, consequently, able to create a more open democratic society and improve the well-being of citizens. 
The results of the researches by scientists, analysts and politicians are introduced in the democratic management model - Good Governance, which embodies new public administration, new regionalism. Moreover, «good public governance identified as the consolidation of interests and regulation of relations between different people, organizations and other stakeholders in a society is becoming increasingly important» (Katsamunska, 2016, p. 139).

In the scientific works by Western scientists Sorensen \& Torfing (2005), Torfing \& Triantafillou(2013), Osborne (2006),Bryson, Crosby \& Bloomberg (2014) a somewhat similar, but more refined idea is the formation of New Public Governance principles, which are directed to creating an effective public administration systems, introduction of innovative models, technologies, widespread use of benchmarking, involvement of business and civic environment in public administration through partnership mechanisms and collaboration.

In the Ukrainian scientific space in relation to the impact on the tourism industry in the context of its support and establishment, application and enforcement of regulations, the concept of state regulation is usually used. However, in the light of current world realities, particularly in legal doctrine and legal science, the separation of the right to public and private (juspublicum and jusprivatum) is crucial. For the first time, the importance of this division was realized in ancient Rome. The Roman jurist Ulpianus (Domitius Ulpianus, 170-228) differentiated this concept in the following way: public law refers to the position of the Roman state, private to the benefit of individuals. Hence, private law is the sphere of freedom and decentralization, public law is the sphere of necessity and centralism.

In private law there are expressed the private interests of individuals and their associations, non-governmental entities. Decentralized regulation of social relations takes place on the basis of coordination. It means on the principles of legal equality, autonomy of such entities, and the presumption that «All that is not forbidden is allowed». Oppositely, in public law the legal priority belongs to the interests of the state, there is a centralized regulation of public relations by the state government, and the presumption is «All that is not allowed by law is directly prohibited». By applying the logic of these provisions to regulating the relations in the national tourism system, there can be distinguished the public regulatory influence on the social relations that arise in it.

The evolutionary development of NTS public governance is characterized by ambivalent processes, different approaches to its semantics and problem solving, models, principles and mechanisms of functioning and development. Therefore, under the influence of post-industrial changes the dynamic development of the society requires constant improvement of the quality of governance. In view of this, there is a need to implement modern principles of public governance in the functioning of the national tourism system.

Presenting main material. The essence of public governance involves the formation of the organizing and regulating influence of the state on the social life of 
people with the purpose of ordering, preserving or transforming it. And «the overarching concept in governance in public policy terms is the relationship between state intervention/public authority and societal autonomy or self-regulation» (Hall, 2011, p. 450).

New Public Governance is based on communication and mutually beneficial cooperation between participants (actors) in the public, private, community sectors, broad stakeholder involvement in decision-making, clear accountability, and reduced regulatory functions. And the very concept of new public governance implies not only changes in public administration, but generally in the functioning of the state: the growth of public activity, the interaction of many interconnected entities (public, private, community) in the formulation of public policy, the involvement of private resources for deciding public issues.

Considering the global trends, in particular the experience of the European community and leading world scientists, it is necessary to take into account the ideas and tools of these concepts of public governance in the process of managing the tourism system.

In the context of the above-said, the spheres of NTS management are considered as: 1) regulation of entrepreneurship, which includes the formation of a regulatory and legal framework for the functioning and development of NTS, a competitive environment for the creation of tourism and tourism-related products and services; 2) management of subjects of NTS of state and communal ownership, first of all, hotels, sanatoriums and other means of temporary settlement (accommodation), as well as establishments in the field of education, science, communal services, construction, trade, etc.; it concerns the establishment of the production of publicly useful goods and services by the state on the basis of the use of state property and under the direct control of public authorities - budget financing, public procurement of services, etc.; 3) it is necessary to single out an additional sphere - the regulation of public-private partnership, as a separate component, the functioning of which leads to a stimulating effect on the development of entrepreneurship, the synergistic effect of the interaction between the public and private sectors; it includes the following forms of cooperation: government contracts, leases, concessions, joint ventures) (Fig. 1).

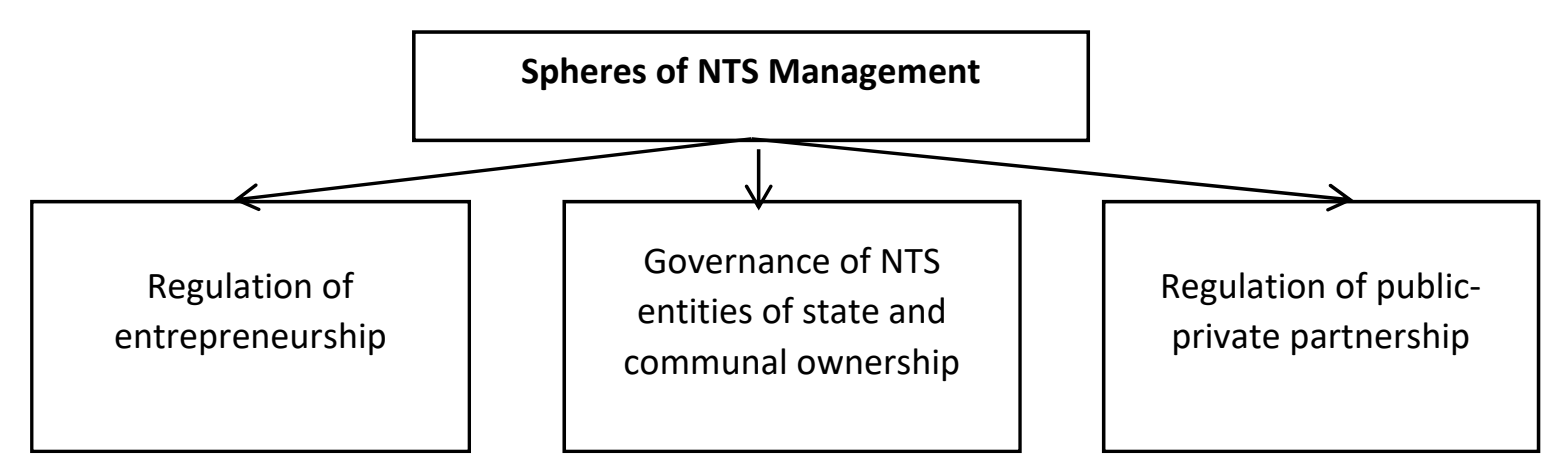

Fig. 1. Generalization of spheres of NTS management

Source: designed by authors. 
The regulatory function of the state is reflected in the development and adoption of legislation in the field of tourism, the establishment of conditions for tourism activity (licensing, certification and standardization in tourism activities, the permit system for the right to carry out tourist conduct, restrictions on the activities of foreign entities, etc.), in providing favorable conditions for tourism development through simplification and harmonization of tax, currency, customs, border and other types of regulation, and in creating a special legal mechanism that provides state control over tourism activities.

In addition, it is necessary to distinguish the following functions of the state, without implementing of which it is impossible to effectively develop the NTS: 1) executive function, aimed at ensuring the application of the established norms in the relations between the subjects of tourism activity, and that is based on the authority and includes measures of prohibition, permit and coercion; 2) controlling function, which is carried out by authorized state bodies and subjects of tourism activity in order to protect the rights and interests of their participants.

The main special means of regulatory influence of the state on the activity of subjects of tourism entrepreneurship in accordance with Art. 12 of the Commercial Code of Ukraine are: licensing; certification and standardization in the field of tourism; definition of qualification requirements for the posts of tourist support employees, issuing permits for the right to carry out tourist conduct; restrictions on the implementation of tour operator and travel agent activities; granting tax benefits and more.

The legal forms of state regulation of tourism activity, as a special type of management, include: normative and legal regulation of the activities of the tourism business subjects; maintenance of the license register of the tour operator activity subjects; issuance of a passport of a tourist object; keeping registers of certificates for the establishment of categories for hotels and other objects intended for providing temporary settlement (accommodation) services; control over keeping to the License conditions of carrying out tour operator activity; the use of measures of influence by authorized state bodies, etc.

A public-private partnership is essential for the effective development of the NTS, which is the focus of the World Tourism Organization (2017), since such cooperation, if properly organized, can be mutually beneficial. The public sector ensures the holistic development of the NTS and its long-term strategy. The private sector implements tactical decisions flexibly and effectively.

Conclusion. Summarizing the above, it is worth noting that the evolutionary management of the NTS was formed under the influence of socio-historical processes. Different concepts and approaches had a significant impact on its development and formation. The focus of in this research is put on the vision of NTS in the context of public governance, which should be based on the values of civil society, democracy, partnership between the state, private and public entities. After all, the process of becoming and building a sovereign democratic socio-legal statehood is accompanied by the approval of new principles of the economic system based on market relations and the development of entrepreneurship, the formation of civil society and the establishment of qualitatively new democratic institutions of public authority. 
The main spheres of NTS governance are identified and it is proposed to considered them as a synergistic concept of effective regulatory influence on the tourism system functioning: regulation of entrepreneurship, formation of a competitive environment for the creation of tourism and tourism-related products and services; management of NTS entities of state and communal ownership; ensuring the effective functioning of publicprivate partnerships.

\section{REFERENCES}

1. Bryson, J.M., Crosby, B.C. \& Bloomberg, L. (2014). Public Value Governance: Moving beyond Traditional Public Administration and the New Public Management, Public Administration Review, 74(4), 445-456.

2. Hall, C.M. (2011). A typology of governance and its implications for tourism policy analysis, Journal of Sustainable Tourism, 19 (4-5), 437-457. DOI: $10.1080 / 09669582.2011 .570346$.

3. Hospodarskyi kodeks Ukrainy (iz zminamy ta dopovnenniamy) № 436-IV vid 07.02.2019. [Commercial Code of Ukraine (with changes and additions)]. (n.d.). http://zakon.rada.gov.ua/laws/show/436-15

4. Katsamunska, P. (2016). The Concept of Governance and Public Governance Theories, Economic Alternatives, 2, 133-141.

5. Klijn, E.H. \& Koppenjan, J.F.M. (2000). Public Management and Policy Networks, Public Management: An International Journal of Research and Theory, 2(2), 135-158. DOI: 10.1080/14719030000000007

6. Koopmans, M.E., Rogge, E., Mettepenningen E., Knickel K.\& SumaneS. (2017). The role of multi-actor governance in aligning farm modernization and sustainable rural development, Journal of Rural Studies, 59, 252-262. https://doi.org/10.1016/j.jurstud.2017.03.012

7. Mazaraki, A., Boiko, M., Bosovska, M., Vedmid, N. \& Okhrimenko, A. (2018). Formation of National Tourism System of Ukraine, Problems and Perspectives in Management, 16(1), 68-84. http://dx.doi.org/10.21511/ppm.16(1).2018.07

8. Osborne, S.P. (2006). The New Public Governance, Public Management Review, 8(3), 377-387. DOI 10.1080/14719030600853022

9. Ostrom, E. (2009). Workshop in Political Theory and Policy Analysis, Indiana University, Bloomington and Center for the Study of Institutional Diversity, Arizona State University, Tempe, AZ, U.S.A, 408-444.

10. Sorensen, E. \& Torfing, J. (2005). Democratic Anchorage of Governance Networks, Scandinavian Political Studies, 28(3), 195-218.

11. Torfing, A. \& Triantafillou, P. (2013). What's in a Name? Grasping New Public Governance as a Political - Administrative System, International Review of Public Administration, 18(2), 9-25. DOI: 10.1080/12294659.2013.10805250.

12. World Tourism Organization. (2017).Practical Guidelines for Integrated Quality Management in Tourism Destinations - Concepts, Implementation and Tools for Destination Management Organizations. https://www.e-unwto.org/doi/pdf/10.18111/ 9789284417988 